\title{
POTENSI TERJADINYA PERSAINGAN USAHA TIDAK SEHAT PADA PENGGUNAAN APLIKASI PERDAGANGAN ELEKTRONIK DI ERA REVOLUSI INDUSTRI 4.0
}

\author{
Elza Syarief, Rina Shahriyani Shahrullah, Febri Jaya, Jefri Kurniawan; Fakultas Hukum, \\ Universitas Internasional Batam; E-mail : febri.jaya@uib.edu
}

\begin{abstract}
Abstrak
Perkembangan teknologi di era industri 4.0 begitu pesat dan mempengaruhi kebiasaan masyarakat. Perubahan yang paling jelas terlihat adalah semakin banyaknya pelaku usaha yang memanfaatkan aplikasi perdagangan elektronik untuk menjalankan kegiatan usahanya, hal itu juga diikuti dengan minat konsumen yang semakin banyak bertransaksi dengan aplikasi tersebut. Penelitian ini bertujuan untuk mengetahui potensi terjadinya praktik persaingan usaha tidak sehat pada penggunaan aplikasi perdagangan elektronik saat ini, mengingat Undang-Undang Nomor 5 Tahun 1999 tentang Larangan Praktek Monopoli dan Persaingan Usaha Tidak Sehat lahir sebelum revolusi industri 4.0 terjadi. Melalui penelitian hukum normatif diketahui bahwa terdapat beberapa tindakan yang dilarang dan berpotensi terjadi dalam aplikasi perdagangan elektronik seperti oligopoli, penetapan harga, pemboikotan, oligopsoni dan perjanjian tertutup.
\end{abstract}

Kata Kunci: Persaingan Usaha, Perdagangan Elektronik, Revolusi Industri 4.0

\begin{abstract}
The rapid development of technology affects people's habits. The most obvious change is the increasing number of businessmen who use electronic commerce applications such as Tokopedia, Bukalapak and Shopee to carry out their business activities, this has also been followed by consumer trend in making more transactions with these applications. This study aims to determine the potential for unfair business competition practices in the use of electronic commerce applications at this time, considering Law Number 5 of 1999 concerning the Prohibition of Monopolistic Practices and Unfair Business Competition was born before the industrial revolution 4.0 occurred. It is interesting to re-examine whether economic activity in electronic commerce applications can lead to unfair business competition
\end{abstract}

Keywords: Business competition, Electronic Commerce, Industrial Revolution 4.0.

\section{PENDAHULUAN}

\section{Latar Belakang Masalah}

Dampak dari revolusi industri 4.0 di sektor ekonomi mengalami peningkatan, dimana sektor-sektor perdagangan dan Usaha Mikro Kecil dan Menengah (selanjutnya disebut UMKM) meningkat dengan pesat. Bisnis online tidak dipungkiri memberikan dampak positif bagi perkembangan bisnis yaitu memberi peluang bagi para pengusaha baik yang pemula maupun pemain bisnis yang sudah eksisi, namun bisnis online juga memiliki sisi lain bak dua sisi mata uang. Bisnis online juga memiliki dampak negatif yang berupa penipuan baik dari pihak pelaku bisnis maupun konsumen, kompetitor, penipu dan hacker. ${ }^{1}$

Revolusi Industri 4.0 secara perlahan telah mengubah banyak hal dalam kegiatan sehari-hari, bahkan menurut Danrivanto Budhijanto hal tersebut tidak hanya mengubah apa yang manusia lakukan namun juga siapa "kita" sebagai manusia. ${ }^{2}$ Perkembangan

1 Hamdan. (2018). Industri 4.0: "Pengaruh Revolusi Industri pada Kewirausahaan Demi Kemandirian Ekonomi", Journal of Nusamba, Vol. 3 No. 2 Oktober.

2 Budhijanto, Danrivanto. (2019). Cyber Law \& Revolusi Industri 4.0. Bandung: Logoz Publisihing, h. 182. 
teknologi di bidang telekomunikasi yang sangat pesat telah memudahkan kita untuk menggunakan internet dalam kegiatan sehari-hari. Secara kasat mata perubahan yang sangat signifikan terlihat pada kebiasaan transaksi jual beli, kehadiran perusahaan perdagangan elektronik seperti Tokopedia, Bukalapak, Shopee dan lainnya yang menyediakan aplikasi perdagangan elektornik untuk bertransaksi jual beli seolah-olah telah menghapus batasan geografis antara para penjual dan pembeli yang selama ini menjadi salah satu kendala dalam melakukan transaksi jual beli di Indonesia.

Dampak dari Revolusi Industri 4.0 disektor perekonomian khususnya dalam sektor perdagangan elektronik yaitu meningkatnya jumlah pelaku usaha kategori UMKM bahkan beberapa pelaku usaha perdagangan besar pada akhinya ikut menjalankan kegiatan usahanya secara online dengan menggunakan aplikasi perdagangan elektronik, hal ini tentu saja dikarenakan meningkatnya minat konsumen untuk melakukan transaksi melalui aplikasi perdagangan elektronik, walaupun disisi lain berakibat pada kegiatan ekonomi dipasar tradisional yang mengalami penurunan bahkan memaksa perusahaanperusahaan yang selama ini melakukan pemasaran secara offline menjadi pemasaran secara online yang mana berdampak pada tutupnya beberapa cabang dari perusahaanperusahaan tersebut.

Undang-Undang Nomor 5 Tahun 1999 tentang Larangan Praktek Monopoli dan Persaingan Usaha Tidak Sehat (selanjutnya disebut UU No. 5 Tahun 1999) telah merumuskan beberapa tindakan yang dikategorikan sebagai persaingan usaha tidak sehat, namun perlu diingat UU No. 5 Tahun 1999 lahir pada era sebelum revolusi industri 4.0 dimana transaksi dalam perdagangan elektronik belum banyak dilakukan bahkan aplikasi perdagangan elektronik seperti yang disebutkan sebelumnya belum ada dalam kegiatan perdagangan di Indonesia. Hal ini menarik minat penulis untuk meneliti mengenai "Potensi Terjadinya Persaingan Usaha Tidak Sehat dalam Penggunaan Aplikasi Perdagangan Elektronik di Era Revolusi Industri 4.0".

\section{Rumusan Masalah}

Berdasarkan latar belakang tersebut di atas, peneliti ingin meneliti potensi terjadinya persaingan usaha tidak sehat yang dapat merugikan pelaku usaha dan konsumen dalam menggunakan aplikasi perdagangan elektronik saat ini.

\section{METODE PENELITIAN}

Suatu aturan atau hukum positif yang berlaku perlu untuk dikaji secara terusmenerus agar peraturan atau hukum positif yang sifatnya cenderung statis dapat diterapkan secara efektif dalam kehidupan masyarakat yang sangat dinamis, untuk itu Penulis menggunakan metode penelitian hukum normatif untuk meneliti potensi terjadinya persaingan usaha tidak sehat dalam penggunaan aplikasi perdagangan elektronik di era revolusi industri 4.0 saat ini. ${ }^{3}$

Dalam konteks penelitian ini, pokok kajiannya adalah Undang-Undang Nomor 5 Tahun 1999 tentang Larangan Praktek Monopoli dan Persaingan Usaha Tidak Sehat (UU No. 5 Tahun 1999).

\footnotetext{
${ }^{3}$ Sunggono, Bambang. (2003). Metode Penelitian Hukum. Jakarta: PT Raja Grafindo Persada, h. 43 .
} 
Sesuai dengan tipe penelitian yuridis normatif maka data yang dikumpulkan adalah data sekunder. Teknik pengumpulan data dalam penelitian ini, dilakukan dengan desk study. Bahan hukum yang telah terkumpul diklasifikasikan, dianalisis dengan cara menggali asas, nilai serta norma pokok yang terkandung di dalamnya. Hasil penelitian disajikan dalam bentuk uraian-uraian yang tersusun secara sistematis. ${ }^{4}$

\section{PEMBAHASAN}

\section{A. Aplikasi Perdagangan Elektronik sebagai Pasar Bersangkutan}

Apabila membahas mengenai perdagangan maka kita tidak bisa lepas dari membahas mengenai pasar, karena disitulah pelaku usaha dan konsumennya secara langsung atau tidak langsung dipertemukan. Pasar bersangkutan atau relevant market merupakan hal pertama yang harus ditentukan dalam suatu kajian industri, hal ini diperlukan untuk menganalisa dan melihat seberapa besar penguasaan pasar oleh pelaku-pelaku usaha dan batasan-batasan dari tindakan antipersaingan yang dilakukan. 5

Keberadaan aplikasi perdagangan elektronik yang disediakan perusahaan seperti Tokopedia, Bukalapak, dan Shopee menjadi suatu pasar untuk mempertemukan pelaku usaha dengan konsumen secara tidak langsung. Dalam UU No. 5 tahun 1999 pada Pasal 1 angka 10 istilah Pasar Bersangkutan diberikan pengertian ".........adalah pasar yang berkaitan dengan jangkauan atau daerah pemasaran tertentu oleh pelaku usaha atas barang dan atau jasa yang sama atau sejenis atau subtitusi dari barang dan atau jasa tersebut". Melihat pengertian tersebut maka aplikasi perdagangan online merupakan suatu pasar bersangkutan yang lahir dari adanya Revolusi Industri 4.0.

\section{B. Transaksi dalam Aplikasi Perdagangan Elektronik}

Berdasarkan statistik e-commerce 2019 yang diterbitkan oleh Badan Pusat Statistik, sebelum tahun 2010 usaha yang memanfaatkan internet dalam kegiatan usahanya hanya sebanyak 1,53\%, presentasi itu kemudian naik pesat menjadi $45,30 \%$ usaha yang mulai memanfaatkan internet pada rentang tahun 2017 sampai dengan 2018. ${ }^{6}$ Sedangkan untuk jenis barang yang paling banyak dijual yaitu makanan, minuman dan bahan makanan yang kemudian disusul dengan penjualan baju, kemeja, kaos, jaket dan produk-produk tekstil lainnya. ${ }^{7}$

Metode pembayaran yang paling banyak digunakan pada aplikasi perdagangan elektronik yaitu transfer bank, kartu kredit dan pemberian kredit melalui pihak ketiga yang berkerjasama dengan perusahaan perdagangan elektronik. Pengiriman barang dilakukan dengan menggunakan jasa perusahaan ekspedisi seperti JNE, TIKI, Pos Indonesia, JNT dan lainnya. Konsumen bebas memilih metode pembayaran dan jasa pengiriman yang akan mereka gunakan.

\footnotetext{
4 Susetiyo, W., Perdana, M. T., \& Iftitah, Anik. (2020). Perlindungan Hukum dari Paparan Asap Rokok di Kota Blitar. Jurnal Supremasi, 10 (2), 1-8.

${ }^{5}$ Lubis, Andi Fahmi. (2017). Hukum Persaingan Usaha. Jakarta: Komisi Pengawas Persaingan Usaha, h. 61.

${ }^{6}$ Rozama, Nia Anggraini. (2019). Statistik E-Commerce 2019. Jakarta : Badan Pusat Statistik, h. 11.

${ }^{7} \mathrm{Ibid}, \mathrm{h} .15$.
} 
Dalam praktik e-commerce terdapat beberapa model penjualan yaitu sebagai penjual (seller), penjual kembali (reseller) dan perantara penjual dan pembeli (dropshipper). Kemudian untuk jenis pelanggan kegiatan perdagangan elektronik lebih banyak melakukan penjualan ke konsumen akhir. ${ }^{8}$

\section{Potensi Terjadinya Persaingan Usaha Tidak Sehat}

UU No. 5 Tahun 1999 telah merumuskan beberapa perjanjian yang dilarang dalam menjalankan kegiatan usaha untuk tercapainya persaingan usaha yang sehat, dalam penelitian ini model penjualan seperti seller, reseller dan dropshipper yang paling banyak dilakukan dalam aplikasi perdagangan elektronik akan dikaitkan ketentuan-ketentuan dalam UU No. 5 Tahun 1999. Pembahasan pada bagian ini terbatas hanya pada penguasaan pemasaran, penguasaan produksi tidak dikaji dalam penelitian ini dikarenakan penjualan produk dalam aplikasi perdagangan elektronik mayoritas dilakukan antara seller (distributor/agen), reseller, dropshipper dengan konsumen akhir.

\section{Oligopoli}

Oligopoli merupakan suatu bentuk pasar yang terjadi hampir di semua negara. Menurut ilmu ekonomi Oligopoli merupakan salah satu bentuk struktur pasar yang mana didalam pasar tersebut hanya terdapat beberapa perusahaan saja, yang mana perusahaan-perusahaan didalam pasar tersebut mempunyai kekuatan yang relatif cukup besar untuk mempengaruhi harga pasar. ${ }^{9}$

Pasal 4 UU No. 5 Tahun 1999 merumuskan bahwa perjanjian pelaku usaha dengan pelaku usaha lainnya untuk melakukan penguasaan pemasaran barang secara bersama-sama yang dapat menyebabkan terjadinya persaingan usaha tidak sehat dilarang untuk dilakukan. Pelaku usaha patut diduga dan bahkan bisa dianggap melakukan penguasaan pemasaran barang apabila 2 (dua) atau 3 (tiga) pelaku usaha atau suatau kelompok pelaku usaha menguasai lebih dari 75\% (tujuh puluh lima persen) pangsa pasar satu jenis barang.

Penjualan yang dilakukan oleh seller dalam aplikasi perdagangan elektronik saat ini tidak terlalu berpotensi menimbulkan persaingan usaha tidak sehat. Hal ini dikarenakan mayoritas seller dalam aplikasi perdagangan elektronik bukanlah produsen melainkan distributor atau agen, sehingga kekuatan untuk mempengaruhi harga pasar masih belum terlalu kuat. Namun perlu untuk diantisipasi kedepannya apabila perusahaan-perusahaan besar yang merupakan produsen sudah mulai menjadikan aplikasi perdagangan elektronik sebagai sasaran utamanya dan melakukan penjualan seperti seller lainnya. Hal ini mungkin apabila produsen mengubah pola bisnisnya dengan menargetkan konsumen akhir sebagai konsumen utama mereka.

\footnotetext{
8 Ibid, h. 21.

${ }^{9}$ Ibid, Hukum Persaingan Usaha, h. 92.
} 


\section{Penetapan Harga}

Penetapan suatu harga dalam suatu perjanjian yang terdiri dari perjanjian penetapan harga (price fixing agreement), diskriminasi harga (price discrimination), harga pemangsa / jual rugi (predatory pricing) dan pengaturan harga jual kembali (resale price maintenance) dilarang untuk dilakukan oleh UU No. 5 Tahun $1999 .{ }^{10}$ Berikut analisa potensi terjadinya tindakan-tindakan tersebut dalam penggunaan aplikasi perdagangan elektronik.

\section{a. Perjanjian Penetapan Harga (Price Fixing Agreement)}

Tindakan ini merupakan salah satu cara oleh para pelaku usaha untuk menghasilkan laba yang setinggi-tingginya. Jika seller dengan reseller atau dropshipper menetapkan suatu harga tertentu untuk penjualan dalam aplikasi perdagangan elektronik maka akan meniadakan persaingan dari segi harga bagi produk yang mereka jual yang dimana surplus yang seharusnya dinikmati oleh konsumen beralih ke seller, hal ini berpotensi terjadi pada kegiatan usaha dalam aplikasi perdagangan elektronik.

\section{b. Perjanjian Diskriminasi Harga (Price Discrimination Agreement)}

Pada prakteknya seller mencari reseller atau dropshipper yang ingin bekerjasama dengannya untuk memasarkan 1 produk dengan 1 merek yang sama, dalam kerjasama tersebut biasanya dibuat suatu kesepakatan mengenai harga modal yang ditawarkan oleh seller kepada reseller atau dropshipper, hal ini berpotensi menimbulkan persaingan usaha tidak sehat jika seller dengan salah satu reseller atau dropshipper membuat suatu perjanjian bahwa harga modal yang diberikan seller kepada reseller atau dropshipper lainnya harus lebih tinggi dari pada harga modal yang mereka sepakati. Tindakan tersebut dilarang untuk dilakukan berdasarkan Pasal 6 UU No. 5 Tahun 1999.

\section{c. Harga Pemangsa atau Jual rugi (Predatory Pricing)}

Pasal 7 UU No. 5 Tahun 1999 juga melarang pelaku usaha membuat perjanjian dengan pelaku usaha pesaingnya seperti antara seller merek A dan seller merek B dengan jenis produk yang sama untuk menetapkan harga dibawah harga produksi dipasar yang mana dapat mengakibatkan terjadinya persaingan usaha tidak sehat.11 Jika tindakan ini dilakukan maka kompetitor baru akan sulit untuk masuk ke pasar dan bersaing dengan pelaku usaha lainnya dan hal ini merugikan konsumen dan merupakan tindakan antipersaingan. Namun tindakan ini jarang sekali dilakukan oleh para pelaku usaha dikarenakan resikonya yang sangat tinggi.

\section{d. Penetapan Harga Jual Kembali (Resale Price Maintenance)}

Penetapan harga jual kembali dibagi menjadi dua macam, yaitu penetapan harga secara maksimum dan penetapan harga secara minimum. Penetapan harga secara maksimum merupakan perjanjian yang melarang pelaku usaha untuk menjual harga lebih mahal dari yang disepakati, hal ini sebenarnya menguntungkan konsumen agar terhindar dari harga yang tidak wajar. Sebaliknya

10 Ibid, Hukum Persaingan Usaha, h. 95.

11 Ibid, Hukum Persaingan Usaha, h. 99. 
pada penetapan harga secara minimum para pelaku usaha dilarang menjual dengan harga dibawah yang telah disepakati, hal ini biasanya dilakukan oleh produsen kepada distributor.

Berdasarkan penjelasan diatas maka potensi terjadinya persaingan usaha tidka sehat dalam aplikasi perdagangan elektronik yang disebabkan oleh penetapan harga jual kembali hampir tidak ada. Hal ini dikarenakan mayoritas para pelaku usaha merupakan distributor atau agen. ${ }^{12}$

\section{Pembagian Wilayah}

Berdasarkan Pasal 9 UU No. 5 Tahun 1999, perjanjian antara pelaku usaha yang bertujuan untuk membagi wilayah pemasaran atau alokasi pasar terhadap barang tidak boleh dilakukan jika mengakibatkan persaingan usaha tidak sehat, jika sepintas membaca aturan tersebut maka kita akan sepakat hal ini baru berlaku jika perdagangan dilakukan tanpa melalui aplikasi perdagangan elektronik.

Saat ini terdapat beberapa aplikasi perdagangan elektronik seperti Tokopedia, Bukalapak, Shopee dan lainnya, maka bagaimana jika antar pelaku usaha membuat suatu perjanjian yang isinya bahwa Pelaku Usaha A hanya dapat menjual produknya dalam aplikasi Tokopedia dan Pelaku Usaha B hanya dapat menjual produknya dalam aplikasi Bukalapak, apakah dapat kita analogikan masing-masing aplikasi perdagangan elektronik tersebut sebagai suatu wilayah.

Hal ini perlu dipertimbangkan untuk kedepannya mengingat perkembangan kegiatan usaha pada aplikasi perdagangan elektronik begitu pesat. Namun jika berkaca pada prakteknya saat ini hal tersebut sukar terjadi, apalagi jika mencoba menganalogikan suatu wilayah dengan suatu aplikasi perdagangan, pastinya terdapat pro dan kontra terhadap hal tersebut, sehingga untuk saat ini dapatlah disimpulkan bahwa terjadinya persaingan usaha tidak sehat yang dikarenakan pembagian wilayah hampir tidak mungkin terjadi dalam kegiatan usaha dalam menggunakan aplikasi perdagangan elektronik.

\section{Pemboikotan}

Perjanjian antar pelaku usaha yang bertujuan untuk secara tidak langsung memaksa pelaku usaha lain keluar dari pasar yang sama merupakan suatu tindakan persaingan usaha tidak sehat yang pada UU No.5 tahun 1999 dikenal dengan istilah Pemboikotan. Hal ini tentu saja tidak bisa dilakukan oleh satu pelaku usaha saja, semakin banyak pelaku usaha yang membuat perjanjian tersebut semakin besar pula tingkat keberhasilan mereka untuk mengeluarkan pelaku usaha lainnya dari persaingan. ${ }^{13}$

Perjanjian antara seller dengan reseller atau dropshipper yang memuat ketentuan reseller atau dropshipper tidak boleh menjual produk sejenis dengan merek yang lain dilarang dalam Pasal 10 UU No. 5 Tahun 1999 dengan indikator bahwa perbuatan tersebut telah merugikan atau diduga akan merugikan pelaku usaha lainnya dan membatasi pelaku usaha lainnya untuk menjual barang di pasar bersangkutan.

12 Ibid, Hukum Persaingan Usaha, h. 102.

${ }^{13}$ Ibid, Hukum Persaingan Usaha, h. 107. 
Tindakan ini berpotensi untuk terjadi dalam kegiatan usaha padaaplikasi perdagangan elektronik mengingat banyaknya kerjasama yang dilakukan antara satu seller dengan beberapa reseller atau dropshipper.

\section{Kartel}

Sebagaimana dijelaskan sebelumnya bahwa Oligopoli jika dilihat dari prespektif ilmu ekonomi merupakan suatu struktur pasar dimana hanya terdapat beberapa pelaku usaha saja dalam pasar tersebut, struktur pasar yang seperti itu memungkinkan untuk terjadinya suatu praktek kartel dimana para pelaku usaha bekerja sama untuk menentukan harga produk dan jumlah produksi.

Praktek kartel merupakan cara yang dilakukan oleh para pelaku usaha untuk mempengaruhi harga dengan mengatur jumlah produksi mereka. Hal ini tentu berkaitan dengan penawaran (supply) and permintaan (demand), jika jumlah produksi diatur menjadi lebih sedikit dari pada pemintaan maka produk dipasar harga akan naik dan begitu juga sebaliknya jika produk mereka dipasar melimpah jumlahnya maka harga pun akan turun. Namun praktek kartel ini tidak selalu berhasil karena sering sekali para pelaku usaha mencurangi pelaku usaha lainnya untuk kepentingan mereka sendiri.

Praktek kartel tersebut diatas dilarang berdasarkan Pasal 11 UU No.5 tahun 1999 dan pada kegiatan usaha dalam aplikasi perdagangan elektronik, potensi terjadinya praktek kartel tersebut sangat kecil sekali kemungkinannya untuk terjadi pada saat ini, dikarenakan pelaku usaha dalam aplikasi perdagangan elektronik bukan merupakan produsen, seperti yang dijelaskan sebelumnya salah satu cara agar praktek kartel berhasil adalah dengan memainkan jumlah produksi barangnya.

\section{Trust}

Pasal 12 UU No. 5 Tahun 1999 melarang para pelaku usaha melakukan praktek trust yang dapat mengakibatkan terjadinya persaingan usaha yang tidak sehat. Untuk dapat menguasai pemasaran produk bisa saja para pelaku usaha membentuk suatu gabungan perusahaan atau membuat perusahaan yang lebih besar namun tetap mempertahankan dan menjaga kegiatan usaha masing-masing perusahaannya. Trust merupakan suatu wadah yang digunakan untuk membatasi persaingan usaha dalam suatu pasar.

Praktek trust dalam aplikasi perdagangan elektronik sangat kecil kemungkinannya untuk terjadi saat ini, dikarenakan hanya model penjualan seperti seller, reseller dan dropshipper yang ada dalam kegiatan usaha dalam praktik perdagangan elektronik. Praktek trust ini pun dapat dilakukan oleh perusahaanperusahaan besar yang juga merupakan produsen dari suatu produk, sehingga mengingat dalam aplikasi perdagangan elektronik para pelaku usaha mayoritas bukanlah produsen maka praktek trust sangat kecil kemungkinannya untuk terjadi.

\section{Oligopsoni}

Bentuk pasar oligopsoni ialah dimana sejumlah konsumen memiliki kontrol atas pembelian. Praktek oligopsoni ini cukup unik, karena biasanya konsumenlah yang menjadi korban, namun pada praktek oligopsoni yang menjadi korban adalah 
produsen atau seller, hal ini disebebkan para konsumen membuat kesepakatan untuk tujuan agar mereka secara bersama-sama dapat menguasai pembelian dan akhirnya dapat mengendalikan harga atas barang-barang atau jasa-jasa pada pasar bersangkutan.

Untuk berhasilnya praktek oligopsoni terdapat beberapa syarat. Pertama, pelaku usaha harus setuju untuk bekerjasama. Kedua, para konsumen merupakan pembeli dalam jumlah besar atau dominan. Ketiga, kesepakatan antara para konsumen ditaati dan tidak ada kecurangan dan terakhir harus mampu mencegah pembeli dominan baru.

Pada kegiatan perdagangan dalam aplikasi perdagangan elektronik, mayoritas pembeli adalah konsumen akhir dan barang-barang yang paling banyak dibeli adalah makanan, minuman dan pakaian atau barang-barang tekstil, maka dari hal tersebut dapat dipahami bahwa potensi terjadinya persaingan usaha tidak sehat yang dikarenakan praktek oligopsoni sangat kecil kemungkinannya untuk terjadi.

\section{Integrasi Vertikal}

Hubungan antara pelaku usaha dengan pelaku usaha lainnya seperti kompetitornya atau para produsen adalah sesuatu hal yang wajar dalam kegiatan usaha. Namun ketika pelaku usaha tersebut ingin membuat pangsa pasarnya menjadi lebih besar biasanya pelaku usaha akan melakukan merger atau penggabungan atau kerjasama dengan beberapa pelaku usaha lainnya yang secara vertikal berada dilevel yang berbeda pada level produksi. Integrasi vertikal terjadi ketika satu pelaku usaha membuat kerjasama dengan pelaku usaha lain yang berada pada level berbeda dalam satu proses produksi, seolah-olah pelaku-pelaku usaha tersebut merupakan satu perusahaan yang melaksanakan dua aktivitas yang tingkatannya berbeda pada satu proses produksi.

Berdasarkan penjelasan diatas maka potensi untuk terjadinya persaingan usaha tidak sehat yang disebabkan oleh praktek integrasi vertikal yang dilarang oleh Pasal 14 UU No. 5 tahun 1999 sangat kecil sekali untuk terjadi pada saat ini dikarenakan pelaku usaha dalam aplikasi perdagangan elektronik merupakan distributor atau agen dan tidak terkait dengan proses produksi.

\section{Perjanjian Tertutup}

Perjanjian tertutup dikenal juga dengan istilah exclusive dealing yang merupakan suatu perjanjian yang dibuat antara pelaku usaha yang berada pada level yang berbeda pada proses produksi atau jaringan distribusi suatu barang. Perjanjian tertutup terdiri beberapa jenos yang akan dijelaskan berikut ini.

\section{a. Exclusive Distrbution Agreement}

Pelaku usaha membuat perjanjian dengan pelaku usaha lainnya yang dimana terdapat klausula bahwa pelaku usaha yang menerima produk hanya akan memasok dan tidak akan memasok kembali barang tersebut kepada pihak tertentu, 
sederhananya pihak distributor hanya boleh memasok produk pada pihak tertentu dan pasar tertentu saja oleh pihak produsen. ${ }^{14}$

Hal ini berpotensi untuk terjadi jika seller yang merupakan distributor atau agen hanya boleh menjual produk di aplikasi perdagangan online tertentu oleh produsen, sehingga bisa saja keadaannya seller $A$ hanya boleh memasok di Tokopedia, seller $B$ hanya boleh memasok di Bukalapak dan seterusnya, praktek ini dapat menghilangkan persaingan dalam tingkat distributor yang mana akan merugikan konsumen. Perbuatan ini dilarang oleh Pasal 15 ayat (1) UU No. Tahun 1999.

\section{b. Tying Agreement}

Jika suatu pelaku usaha membuat kesepakatan atau perjanjian dengan pelaku usaha lainnya pada tingkatan atau level yang berbeda dengan syarat penjualan suatu barang hanya dapat dilakukan apabila pembeli juga membeli barang lainnya, maka hal tersebut merupakan praktek tying agreement yang dilarang oleh Pasal 15 ayat (2) UU No.5 tahun 1999.

Potensi terjadinya praktek tying agreement dalam perdagangan di aplikasi perdagangan elektronik tidak mungkin untuk terjadi, sistem jual-beli yang disediakan tidak memungkinkan pelaku usaha untuk melakukan hal tersebut.

\section{c. Vertical Agreement on Discount}

Perjanjian ini dibuat jika pelaku usaha ingin mendapatkan potongan harga untuk produk tertentu yang ingin dibelinya dari pelaku usaha lain, pelaku usaha tidak akan membeli produk sejenis dari pelaku usaha lain, akibatnya pelaku usaha lain dengan produk sejenis akan kesulitan menjual produknya dan membatas hak konsumen yang seharunya dapat memilih produk merek apa saja yang mereka inginkan.

Praktek tersebut diatas dilarang oleh Pasal 15 ayat (3) UU No.5 tahun 1999, dimana potensi untuk terjadinya dalam perdagangan elektronik mungkin saja terjadi, khususnya untuk jenis produk yang memang tidak banyak dijual oleh pelaku usaha dalam aplikasi perdagangan elektronik.

10. Perjanjian Dengan Pihak Luar Negeri

Pasal 16 UU No. 5 Tahun 1999 melarang pelaku usaha untuk membuat perjanjian dengan pihak dari luar negeri yang memuat klausula yang dapat menyebabkan terjadinya persaingan usaha tidak sehat. Jika dikaitkan dengan perdagangan yang dilakuakan dalam aplikasi perdagangan elektronik saat ini hal ini hampir tidak mungkin terjadi, berkaca pada perdagangan secara umum, kasus yang disebabkan oleh praktek tersebut juga sangat jarang sekali terjadi, hal ini dikarenakan kesulitan-kesulitan dalam penerapannya. ${ }^{15}$

${ }^{14} \mathrm{Ibid}$, Hukum Persaingan Usaha, h. 125.

${ }^{15} \mathrm{Ibid}$, Hukum Persaingan Usaha, h. 131. 


\section{PENUTUP}

Dari hasil telaah yuridis berdasarkan UU No. 5 Tahun 1999 mengenai perjanjian yang dilarang, maka dapat disimpulkan bahwa terdapat beberapa tindakan yang dilarang dan berpotensi untuk terjadi dalam aplikasi perdagangan elektronik saat ini, seperti oligopoli, penetapan harga, pemboikotan, oligopsoni dan perjanjian tertutup. Namun untuk mengetahui adanya tindakan praktik persaingan usaha dalam aplikasi perdagangan elektronik sangat sulit dikarenakan tidak adanya hubungan langsung antara para pelaku usaha maupun antara pelaku usaha dengan konsumen dalam aplikasi perdagangan elektronik dan menurut hemat Penulis untuk melakukan tindakan persaingan usaha tidak sehat dalam aplikasi perdagangan elektronik pun sangat sulit untuk dilakukan saat ini, dikarenakan para pelaku usaha bukanlah produsen melainkan hanya distributor atau agen bahkan reseller atau dropshipper saja dan konsumen yang paling banyak adalah konsumen akhir.

Terlepas dari kecilnya potensi untuk terjadinya persaingan usaha tidak sehat pada kegiatan usaha dalam aplikasi perdagangan elektronik, sudah saatnya pemerintah mempersiapkan instrumen, lembaga atau aturan-aturan mengenai persaingan usaha tidak sehat untuk mengantisipasi perkembangan kegiatan usaha dalam aplikasi perdagangan elektronik untuk kedepannya, mengingat perkembangannya yang begitu pesat, bukanlah tidak mungkin persaingan usaha tidak sehat dalam aplikasi perdagangan elektronik akan terjadi dalam jumlah yang banyak atau bahkan tidak menampik kemungkinan bahwa kedepannya dapat terjadi praktek persaingan usaha tidak sehat yang bahkan dilakukan oleh penyedia aplikasi perdagangan elektornik.

\section{DAFTAR PUSTAKA}

Budhijanto, Danrivanto. (2019). Cyber Law \& Revolusi Industri 4.0. Bandung: Logoz Publishing.

Hamdan. (2018). "Industri 4.0: Pengaruh Revolusi Industri pada Kewirausahaan Demi Kemandirian Ekonomi". Journal of Nusamba, Vol 3 No. 2 Oktober 2018.

Lubis, Andi Fahmi. (2017). Hukum Persaingan Usaha. Jakarta: Komisi Pengawas Persaingan Usaha.

Rozama, Nia Anggraini. (2019). Statistik E-Commerece 2019. Jakarta: Badan Pusat Statistik. Sudikono Mertokusumo. (1991). Mengenal Hukum (Suatu Pengatar). Yogyakarta: Liberty. Sunggono, Bambang. (2003). Metode Penelitian Hukum. Jakarta: PT Raja Grafindo Persada. Susetiyo, W., Perdana, M. T., \& Iftitah, Anik. (2020). “Perlindungan Hukum dari Paparan Asap Rokok di Kota Blitar". Jurnal Supremasi, 10(2).

Zainuddin Ali. (2016). Metode Penelitian Hukum. Jakarta: Sinar Grafika. 